\title{
2.7 Творчо-виконавська підготовка майбутнього викладача музичних дисциплін у контексті вищої мистецької освіти
}

Динамічні інтеграційні соціально-економічні процеси вимагають розв’язання актуальних завдань, зумовлених об'єктивною потребою суспільства у конкурентоспроможних фахівцях, здатних демонструвати високий рівень професіоналізму, освіченості й культури, визначати способи особистісного розвитку й саморозвитку. У зв'язку з цим, перед вищою мистецькою освітою постали важливі завдання: підготовка свідомої національної інтелігенції, оновлення та збагачення інтелектуального генофонду нації, виховання ії духовної еліти, примноження культурного потенціалу, що має забезпечити високу ефективність діяльності майбутніх фахівців як провідників високої художньої культури, творців, активних учасників освітньо-культурного процесу.

3 огляду на такі завдання постала потреба реконструкції змісту професійної підготовки майбутніх фахівців, інтенсивного впровадження в практику навчання і виховання інноваційних методик, технологій і підходів, спрямованих на активізацію суб'єктних можливостей кожного студента, розвиток його духовності і творчої індивідуальності, культури мислення і почуттів.

Вища освіта - це процес і результат поєднання навчання і професійної підготовки, що передбачає оволодіння найновішими досягненнями науки i практики, грунтовне і фундаментальне засвоєння систематизованих знань, спроможність самостійно і відповідально виконувати службові чи виробничі функції, творчо використовувати i розвивати досягнення науки, техніки i культури; розвиток особистості студента, його інтелектуальних і моральних якостей, формування гармонійної індивідуальності, потреби у подальшому самовдосконаленні та безперервній освіті [105, с. 99].

Освіта - це знання, компетентності, професіоналізм, світогляд, цінності, фізичний і духовний стан особистості. I саме від того, які якості останньої ми сформуємо у процесі освіти і виховання, багато в чому буде залежати вигляд нашого майбутнього світу [100, с. 16]. 
Тлумачення поняття «освіта» в Українському педагогічному словнику С. Гончаренка містить спрямованість освіти на духовний розвиток особистості, формування іï внутрішнього світу, особистісних якостей (культурологічний, антропологічний, аксіологічний, особистісно зорієнтований аспекти) й розкривається як «духовне обличчя людини, яке складається під впливом моральних і духовних цінностей, що є надбанням ії культурного кола, а також процес виховання, самовиховання, впливу, шліфування, тобто процес формування обличчя людини. При цьому головним $є$ не обсяг знань, а поєднання останніх з особистісними якостями, вміння самостійно розпоряджатися своїми знаннями» [102, с. 242].

Здійснюючи системне дослідження освіти та педагогічної освіти як складноорганізованих соціокультурних феноменів, як спеціалізованого компонента в соціальному організмі (який самоорганізовується, самозберігається, саморозвивається), протистоїть стихійним i тому малоефективним культурним механізмам передачі досвіду, необхідного для відтворення суспільного життя [108, с. 13]. В. Луговий трактує освіту як процес і результат цілеспрямованого формування культури людини, уточнюючи, що мова йде не про культуру людини, а про культуру суб'єкта діяльності, яким можуть бути і окрема людина, і соціальна група, і людство загалом [108, с. 12].

На підставі аналізу наукових праць можемо зробити висновок, що до особистості вчителя, до якості його професійно-педагогічної діяльності й до самого вчителя як суб'єкта навчально-виховного процесу висуваються нові вимоги, що ефективно впливають на розширення комплексу взаємопов'язаних завдань, які покладаються на педагогічну освіту загалом й музично-педагогічну зокрема. Основними 3-поміж них Н. Ничкало виокремлює [111, с. 25]:

- створити необхідні соціально-культурні і соціально-економічні умови для розвитку особистості студента вищого навчального закладу - майбутнього педагога, для його фундаментальної загальнокультурної підготовки, формування високих морально-етичних якостей, любові до педагогічної професії, відданості їй; 
- сприяти професійному становленню, самовдосконаленню педагога;

- стимулювати інноваційну діяльність у різних освітньо-виховних системах, педагогічну творчість, що дає можливість досягти рівня педагогічної майстерності [120, с. 255].

Подамо оригінальні концептуальні визначення освіти та їі мети:

- «пакетне поняття», простір адекватних інтерпретацій якого за обсягом змістового i функціонального навантаження співвідноситься 3 терміном «культура», конституюється в просторі як індивідуального, так і соціального (Л. Масол) [109, с.6];

- процес або результат засвоєння визначених суспільством рівнів культурної спадщини та пов'язаний з ним рівень індивідуального розвитку; передача і присвоєння культурного досвіду як трансляція цілісної картини світу, поза якою неможлива цілісна особистість як повноцінний суб'єкт культури (О. Олексюк) $[112$, с. 6];

- процес і результат засвоєння систематизованих наукових знань, умінь і навичок про соціальну сутність і зміст конкретної професійної діяльності, як необхідну умову для підготовки людини до здійснення соціально-професійних функцій на належному освітньо-кваліфікаційному рівні О. Єременко [106];

- забезпечення кожному, хто навчається, широкі можливості для здобуття знань про людину, суспільство, формування наукової картини світу як основи світогляду, досвіду суспільних і особистісних відносин, комунікативної і творчої діяльності, що відкриває простір для розвитку індивідуальних здібностей особистості, забезпечує ії підготовку до активної участі у житті країни (Л. Дичківська) [104, с. 9-10];

- підготовка учня до життя, до його самовираження в різних галузях діяльності, а для цього, додає педагог, насамперед потрібно забезпечити готовність учня до навчальної і трудової діяльності, його здатність переносити знання про об’єкт і способи дії з однієї галузі в іншу, формування раціонального стилю самостійної діяльності, здатність застосовувати знання в житті [М. Ржецький 116, с. 11]; 
- формування і розвиток особистості, яка характеризується творчою індивідуальністю, високим рівнем соціальної зрілості, освіченості, культури, розумінням сутності суспільства і людини та їх взаємозв'язку у процесі розвитку [О. Семеног 119, с. 81].

- ціннісне світоглядне ставлення особистості до соціального і природного навколишнього світу і самої себе, розвитку свідомості, культури мислення і культури почуттів особистості, що передбачає усвідомлення нею, перш за все моральних, духовних, естетичних цінностей, які становлять мету існування людини [Л. Хомич 121, с. 89];

- процес і результат формування якостей особистості засобами навчання і виховання відповідно до норм духовної культури і цінностей суспільства. Освіченість означає різнобічний розвиток особистості і $є$ результатом реалізації багатоаспектного змісту освіти (О. Рудницька) [118, с. 22].

Вченою уведена у науковий обіг категорія «мистецька освіта», яка визначається як «освітня галузь, що спрямована на розвиток у людини спеціальних здібностей і смаку, естетичного досвіду і ціннісних орієнтацій, здатність до спілкування з художніми цінностями у процесі активної творчої

Метою мистецької освіти визначається:

- подолання художньої однобічності сприймання і розуміння образного змісту художніх творів різних видів мистецтв [118, с. 29-30].

- розв'язувати завдання підготовки особистості до аматорської i професійної мистецької діяльності, оволодіння її технікою та технологією [114, c. 40].

стимулювання художнього самопізнання, сприяння творчій самореалізації особистості, формування ставлення учня до себе, свого внутрішнього світу [109, с. 22];

цілеспрямоване засвоєння музичної культури; взаємодія діяльності викладача (поєднанням навчання i виховання) i діяльності вихованця (формування та творче використання музичних знань, умінь і навичок) [112, с. $6]$; 
- процес і результат засвоєння музичних знань, умінь і навичок, що свідчить про відповідний рівень опанування музичних явищ в аналітичнотеоретичному або практично-виконавському аспектах $[110$, с. 73 - 74];

- складний діалектичний процес розвитку художньо-творчих здібностей учнів, їх здатності до естетичного сприймання, переживання i творення музики; розвиток особистості учня [117, с. 193];

- ормування духовного світу людини, закономірності гармонізації іiі життя, забезпечення природного входження до соціального середовища» $[115$, с. $5]$;

- спрямованість на «індивідуалізоване становлення професійно значущих якостей і здібностей, професійних знань та вмінь, перетворення особистістю свого внутрішнього світу та творчу самореалізацію у професії» [113, c. 73].

В умовах сучасного осмислення i підходу вища мистецька освіта розглядається в трьох взаємозумовлених аспектах: змісту, функціонування i розвитку, є системою, що саморозвивається й характеризується фундаментальністю, універсальністю, гуманітарною і науково-дослідною спрямованістю. Ця система орієнтує студентів мистецьких спеціальностей на освоєння фундаментальних і грунтовних загальнотеоретичних, спеціальних, психолого-педагогічних знань, на набуття науково-дослідницьких і практичних умінь для творчого оперування ними під час розв’язання професійних завдань.

У системі музично-педагогічної освіти дисципліни компонуються за напрямами і передбачають професійно орієнтовану гуманітарну та соціальноекономічну, професійно-педагогічну підготовку i виконують функцію соціалізації студентів завдяки системі знань, розкривають узагальнений i науково осмислений досвід ставлення людини до себе, інших, суспільства, спонукають особистість до самовизначення, сприяють формуванню життєвої позиції, світогляду, допомагають у самовизначенні, формуванні життєвих установок, адекватного ставлення до навколишнього середовища. 
У змісті професійної підготовки особливе значення має фахова підготовка майбутнього вчителя як система музично-теоретичних (у тому числі музичноісторичних), музично-виконавських, практично-методичних, науково-дослідних дисциплін, що здійснюється безперервно упродовж всього терміну навчання. Під час вивчення фахових дисциплін майбутні учителі музичного мистецтва оволодівають грунтовними музично-теоретичними, культурологічними, музично-історичними знаннями, художньо-інтерпретаційними і сценічновиконавськими вміннями, набувають знань 3 методики музичного виховання та фахових методик, трансформують їх в освітню практику.

Відзначаючись власною специфікою, характеризуючись внутрішньою спорідненістю й інтеграційністю, фахові дисципліни тяжіють до взаємодоповнення, взаємозумовленості та співіснування й складають окремий блок. Їх складний внутрішній зв’язок виявляється в єдності методології та принципів музично-педагогічної діяльності: від набуття грунтовних музичнотеоретичних знань, художньо-інтерпретаційного, музично-виконавського, практично-методичного досвіду до втілення у практичній діяльності і власній творчості. Завданням фахових дисциплін є розкриття унікальних особистісних якостей майбутнього вчителя, які виявляються у здатності адекватно сприймати й оцінювати художні явища, критично мислити, оволодівати здатністю до самостійного пошуку, що дають змогу успішно здійснювати педагогічну діяльність.

Основу фахової підготовки майбутнього вчителя музичного мистецтва становлять предмети музично-теоретичного циклу - «теоретичні науки», які спрямовані на розвиток музичної грамотності, художньої свідомості, формування у студентів логіки мислення.

Набуття грунтовних музично-теоретичних знань здійснюється через виконавську діяльність на основі художнього осмислення музичних уявлень від елементарної музичної грамоти до музичної грамотності, інтонаційності, цілісного аналізу, розуміння музичної форми, самостійності музичнотеоретичного i музично-виконавського мислення. Музично-теоретична 
підготовка як фундаментальна, передбачає оволодіння закономірностями музичної мови у комплексі з виконавськими вміннями та навичками. Теорія як i граматика, необхідна і важлива у процесі художнього сприймання, музичного виконання, оскільки розширює світогляд, надає знання різних композиційних структур музичного твору, жанрів, розкриває суспільно-історичний розвиток.

У процесі вивчення музично-теоретичних дисциплін розвиваються природжені здібності, інтонаційний слух, почуття метро-ритму, ладу, гармонії, форми, тембру, навички сприйняття і відтворення окремих елементів музичного твору. Студенти не тільки набувають знання, вміння та практичні навички, а усвідомлюють їх якісне перетворення, виробляють прагнення до інтенсифікації творчої самостійності, що збуджує їх дослідницький хист, потребу у самовираженні у всіх видах музичної творчості - сприйнятті - інтерпретації творенні. У цьому поягає універсальність музично-теоретичних дисциплін, адже саме вони покликані формувати вміння i навички, необхідні і вчителю, i музиканту-фахівцю для творчого самовираження i самореалізації, творчої самостійності, в якій взаємодіють різні аспекти психічної діяльності, теоретичні знання, художньо-образне мислення, творчо-виконавські вміння, культура художнього сприйняття, професійна емпатія і рефлексія.

Важливим завданням професійної підготовки $\epsilon$ розвиток творчої особистості майбутнього викладача музичного мистецтва, який уміє орієнтуватися в історико-стильових тенденціях та в закономірностях мистецтва, проникати у зміст музичних творів способом аналітичного мислення-пізнання та емоційно-образного сприйняття-інтерпретації, самовиражатись у різних видах музично-виконавської діяльності. Забезпечення умов адекватного розумінняпізнання мистецького твору, його сприйняття-інтерпретації і творення, розвиток особистості, яка творчо мислить і творчо діє - мета творчо-виконавської підготовки майбутнього викладача музичного мистецтва.

Мистецтво є особливим рівнем людинознавства. Людина звертається до мистецтва у пошуках істини й сенсу життя. Спираючись на ідею гуманності,

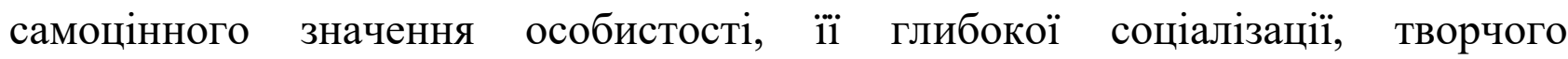


самоствердження та індивідуального світосприйняття, усвідомлюємо, що мистецтво, як ніяка інша форма суспільної свідомості, цілісно й гармонійно впливає на внутрішній світ особистості, сприяє іiі духовному вдосконаленню, розвитку емоційно-інтелектуальної сфери, формуванню культури міжособистісного спілкування, усвідомленню понять про загальнолюдські цінності, критеріїв самооцінки та оцінки навколишньої дійсності, залучає до участі в навколишньому житті, задовольняє потребу особистості в духовному спілкуванні.

Творча глибина мистецьких творів, зазначає О. Рудницька, криється в здатності осмислювати людський досвід на такому рівні, на якому він водночас виявляється і як універсальна загальність, і як неповторна індивідуальність, завдяки чому стає можливим залучити до світу художньої реальності кожну людину. Під впливом художніх образів безпосередні почуття переходять в естетичні, духовні, етичні уявлення суб’єкта як ціннісний акт осягнення світу та самопізнання власної індивідуальної сутності [118].

Оскільки мистецтво є невід’ємною складовою становлення духовно розвиненої особистості, а тому має бути важливим предметом ii навчання i виховання вже з раннього дитинства. Залучення до художньої творчості значно розширює духовний світ людини, узагальнює ієрархію іiї цінностей та смислів, гармонізує внутрішній світ. У цьому відношенні універсальна природа мистецтва надає значні можливості. Як своєрідна «філософія серця», що поєднує мудрість розуму та мудрість серця силою уяви, фантазії художника, мистецтво, в якому закладені ідеї високого гуманізму і «живе краса людського духу» (В. Сухомлинський) найвищою мірою здатне не лише сприяти пробудженню та поглибленню людських почуттів, а й спонукає працювати думку, формує моральні принципи, розширює світогляд, породжує ідеали. Тобто, за допомогою мистецтва людина не тільки пізнає навколишню дійсність, а також формує себе як всебічно розвинену духовну особистість, що є важливим кроком на шляху до духовності як вираження пізнавальної, творчої та моральної активності людини. У цій триєдності творчо-виконавська діяльність займає особливе місце, оскільки 
саме завдяки художньому універсалізму здатна спонукати до дії, породжувати інтерес і потребу в художньому спілкуванні, поєднувати і тісно взаємодіяти 3 інтелектуально-пізнавальною, морально-етичною, особистісно-аксіологічною сферами особистості. Це уможливлюється тим, що об’єктивне й суб’єктивне, свідоме й несвідоме, чуттєво-інтуїтивне й емоційно-образне, інтелектуальнорозумове й рефлексивно-оцінювальне в процесі сприйняття, інтерпретації і творення постають у тісній взаємодії, взаємопроникненні й взаємозбагаченні.

Мистецтво є засобом розвитку людини, оскільки в процесі художнього спілкування особистість одночасно формує у собі щось нове, i насамперед, здатність творити. Творча діяльність в мистецтві постає тому як самодіяльність, самозміна, саморозвиток людини. Можна виокремити два основоположних принципи, завдяки яким мистецтво набуває пріоритетного значення у процесі духовного становлення особистості: художній універсалізм і спрямованість на творчий саморозвиток. Художній універсалізм гармонізує внутрішній світ особистості, розширює межі їі духовного збагачення, спрямованість на творчий саморозвиток удосконалює особистісну сферу, сприяє розвитку творчих можливостей.

Процес художнього спілкування у різних видах творчо-виконавської діяльності найвищою мірою відповідає змісту діалектичної категорії творчості, яка передбачає зміну об'єкта та самозміну, саморозвиток суб'єкта як взаємопов’язані сторони єдиного художнього процесу. Зазвичай, здобутком творчості є процес художнього пізнання, предметним результатом - художня інтерпретація мистецьких творів, адже, щоб стати надбанням соціокультурного універсуму, потенціал художньої творчості має втілитися у реально існуюче багатство художньої культури - твори мистецтва.

Унікальним засобом духовно-творчого розвитку i саморозвитку особистості є музичне мистецтво, котре, узагальнюючи багатовіковий людський досвід духовно-емоційного ставлення до світу, має найбільшу силу емоційного впливу на особистість. Різноманітність почуттів, що запрограмовані митцем, спричиняють неоднозначність художнього переживання, яке містить у собі i 
позитивні, і негативні емоції. Саме вони створюють ефект співпереживання, що здатний змінити систему цінностей особистості, іiі життєві установки, погляди, переконання.

Упродовж всієї історії людства музичне мистецтво $є$ одним із найпотаємніших і найзагадковіших з мистецтв, якому «притаманна абстрактна форма передачі поняттєвого змісту», що об’єктивно зумовлено значно меншою здатністю музичного слуху порівняно із зором інформувати особистість про конкретні матеріальні ознаки певного явища.

На всіх рівнях свого здійснення, унікально-особистісне самовираження художника наповнене соціальним змістом. Але поворотним стрижнем, спрямовуючим вектором цього соціального буття завжди $\epsilon$ індивідуальне начало, елемент «авторства», що міститься в особистісно-духовному досвіді митця. Ця позиція $є$ особливо важливою у процесі творчо-виконавської підготовки майбутніх учителів музичного мистецтва, коли пріоритетними мають виступити не тільки прагнення набувати знань, співчувати й співпереживати, сприймати музичні твори і художні образи не як «щось надособистісне», а як здобуток власного творчого досвіду, усвідомити особистісну здатність творити, потребу розкривати власні почуття і ставлення до навколишнього світу через «інтонаційну мову» мистецтва.

Проблема функцій мистецтва належить до фундаментальних теоретичних питань естетики. Функції визначають закономірно-необхідний характер мистецтва, дають змогу здійснювати художній діалог на рівні епох і культур, розуміти мистецькі твори далеких часів, різних країн і народів.

Основу функцій зумовлює історичний чинник, адже функції мистецтва виникають і складаються впродовж усього розвитку цивілізації у зв'язку 3 формуванням нових потреб і особливостей побуту і поведінки людини. Тому внутрішня мета будь-якої діяльності - це завжди функція, «служба» в системі цілого соціального організму або окремої особистості як суспільної цілісності.

Своєрідною ознакою мистецтва є його тяжіння до поліфункціональності, що сприяє створенню універсальної цілісної художньої моделі світу. 
Поліфункціональність мистецтва спирається на ідею гуманності, самоцінного

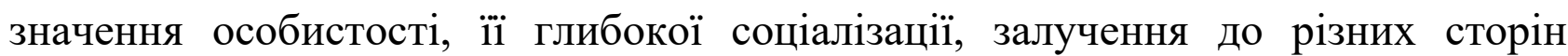
навколишнього життя, творчого самоствердження та індивідуального світосприйняття і набуває своєї значущості в процесі художнього пізнання й далі формує потребу у власному творенні.

Питанням функціональності мистецтва естетична наука займалася ще 3 часів античності, зокрема цій проблемі було приділено значну увагу у теоретичних розробках Аристотеля. Давньогрецький філософ чітко виокремив три основні функції мистецтва: пізнавальну, виховну та функцію емоційного впливу. У процесі подальшої розробки проблеми функціональності естетична думка цілком підтримала ідеї Аристотеля щодо пізнавальної та виховної функцій. Певних коригувань зазнала також інтерпретована античним мислителем функція емоційного впливу. Аристотель тлумачив іiі через давньогрецьке поняття «гедонізм» - чуттєва насолода, тоді як естетика XIX - XX ст. емоційно-чуттєве начало перевела у площину естетичного, розширила аристотелівську модель і визначила такі функції мистецтва: соціальну, пізнавальну, сугестивну, виховну, компенсаційну комунікативну, функцію передбачення, які взаємозумовлені і взаємопов'язані, оскільки мистецькі твори існують як цілісне явище.

На світоглядну функцію мистецтва як на основну вказує О. Рудницька. Мистецтву, зазначає педагог, властива висока чутливість до всього, що відбувається навколо. Воно завжди узагальнює і синтезує найсуттєвіші та найзначніші проблеми людського життя, викликає до них суспільний інтерес. [118].

Долучитись до мистецтва - означає вступити в діалог «соціальних мов», стати причетним до «висловленого чужими словами» світу, пізнати міру причетності митця до універсалій всесвіту, відчути й усвідомити гармонію й ритм його душі у складній структурі художнього діалогу (М. Бахтін, М. Каган). Без художнього діалогу гуманістична і духовна сутність мистецьких творів перестає діяти й функціонувати в полікультурному просторі, втрачає свою 
цінність, а отже, й здатність впливати на особистість. Саме тому «мова» творів відомих митців долає часові кордони, стає зрозумілою, пробуджує в людині творця.

Факт діалогічності $€$ визначальною сутністю і особливістю процесу художнього пізнання, яким притаманні такі атрибути людської свідомості й підсвідомості: ціннісне осягнення, емпатійне чуття, евристичне осяяння, рефлексивний злет тощо. Тож пізнання історичних закономірностей розвитку мистецтва, його поліфункціональності, інтегрувальних та диференціювальних тенденцій, розуміння художньо-образного змісту твору уможливлює здійснення духовного спілкування. У цьому спілкуванні знаходить віддзеркалення «єдність особистостей у рамках духовної культури, їх спільне прагнення до Істини, Добра, Краси.

Саме у формі художнього спілкування реалізується духовний діалог на рівні художніх культур, художніх епох, художніх образів, виникає потреба у повторному спілкуванні 3 навколишнім світом через мистецтво, виникає здатність переживати життя іншої людини зі своїми радощами, тривогами, інтересами, проблемами. У такий спосіб, виявляється гуманістична соціальна потреба, відбувається усвідомлення особистості як найвищої цінності, здійснюються спонуки до саморозвитку і самоформування (В. Біблер), оскільки «дух животворить» (Г. Сковорода).

Як зазначалось, всі функції мистецтва взаємозумовлені і взаємопов’язані, оскільки мистецькі твори існують як цілісне явище. Найбільш обгрунтованими вважаються концептуальні підходи щодо функцій мистецтва відомих філософів Ю. Борєва та М. Кагана. Аналізуючи феномен мистецтва, представники філософської думки різних історичних періодів вказували на його комунікативну перевагу над іншими формами суспільної свідомості. Так, однією із основних функцій М. Каган визначає комунікативну (від лат. соттипісо - спілкуюся), яка має поліфункціональний, інтегративний характер. Для педагогіки продуктивним $\epsilon$ розуміння мистецтва як своєрідного «практичного людинознавства» (М. Каган), об’єктивно-суб' єктивної реальності, невід’ємної від творчості людини, 3 
одного боку, і від культури - 3 іншого. Через мистецтво, зазначає Л. Масол, людина самоактуалізується, усвідомлює власну унікальність [109, с. 41].

До важливих функцій мистецької освіти, науковець додає функції, що забезпечують «входження» особистості як в універсум, так і в культуру певного етносу. Це глобальні феномени людинотворення $i$ культуротворення, які $\epsilon$ інтегрованими, адже «культура суспільства і культура людини як результат привласнення соціокультурних цінностей в індивідуальному досвіді, - це ніби «дві сторони однієї медалі: духовної зрілості людина може досягти шляхом успадкування й розвитку культурних цінностей, а підвищення культури особистості приводить до збагачення культури загалом. Культурноантропологічний вимір акцентує різні форми трансляції культури через систему освіти та виховання, і водночас засоби ії особистісного успадкування людиною» $[109$, c. 54].

Екстраполюючи названі взаємопов’язані функції мистецтва у площину творчо-виконавської діяльності майбутнього вчителя музичного мистецтва, які засобами мистецтва і мають вплинути на цілісний розвиток своїх вихованців, їі функціями визначаємо такі:

- цүіннісно-орієнтаџійну, що полягає в спонуканні особистості до самовизначення, формування життєвої та світоглядної позиції;

- виховну, що зумовлена фундаментальною потребою і здатністю педагога і студента залучати у процес творчості, духовної спільності інших, впливати на внутрішній світ, виховувати цінності, формувати особистісні якості;

- пізнавальну, що передбачає залучення студентів до художньо-образного пізнання світу у процесі художнього сприйняття-інтерпретації-власного творення;

- комунікативну (художньо-діалогічну), завдяки якій студентам надається можливість у процесі художнього полісуб'єктного спілкування здійснити діалог з автором художнього твору;

- творчо-спонукальну, що передбачає активізацію творчо-діяльнісної сфери студента, спонукає студентів до самовираження у власній творчості, 
знаходженні викладачем ефективних практичних методів і прийомів, методичних підходів до розвитку індивідуально-творчої особистості майбутнього вчителя;

- культурологічну, що орієнтує майбутніх учителів музичного мистецтва у процесі творчо-виконавської підготовки на поліхудожній розвиток, формування особистісної культури, культури художнього сприйняття, здатності до адекватного сприйняття й розуміння художнього образу;

- гедоністичну $і$ катарсичну, що передбачає акцентування ролі художньої насолоди у процесі сприйняття-інтерпретації, співтворчості і самотворчості.

Педагогічними важелями у досягненні стану художньої задоволеності і насолоди мають стати такі, які пов'язані 3 осягненням, усвідомленням і розумінням художньо-образного змісту художніх творів, здатністю пережити глибокі почуття, відтворені автором в художньому творі, пройнятися тими переживаннями, що їх втілив автор в художньо-образному змісті твору, усвідомити формотвірні засоби i неповторну красу змістових вимірів художнього образу [115].

Як складне системно-інтеграційне і процесуально-результативне утворення, творчо-виконавська підготовка визначає якісно новий рівень професійної підготовки майбутнього вчителя музичного мистецтва, передбачає розвиток його професійно-особистісних якостей, емоційно-ціннісного ставлення до мистецьких цінностей, явищ педагогічної реальності, здатності до самовираження і самореалізації у професійній діяльності і життєтворчості.

Творчо-виконавська підготовка охоплює фахові дисципліни, передбачає зв’язки $з$ дисциплінами інших циклів, грунтується на оптимальній кількості вихідних і логічно пов’язаних наукових підходів і принципів, що визначають иї методологічно-концептуальні основи та організаційно-методичний супровід.

Виявити творчі можливості студента, які ще є прихованими, не очікувати, коли майбутній учитель виявиться як творча особистість у майбутній діяльності, а в умовах навчання у ВНЗ «вивільнити» його творчі здібності і можливості, виявити його унікальність і неповторність, спрямувати творчу діяльність у 
педагогічне русло - важливе завдання творчо-виконавської підготовки майбутнього викладача музичного мистецтва.

Творчість все більше стає характерною рисою фахівців різних напрямів професійної підготовки і спеціальностей, особливо вчителів музичного мистецтва. Багатогранна творчо-виконавська діяльність вимагає від викладача музичного мистецтва бути соціально зрілою, освіченою, ерудованою, інтелектуальною особистістю зі сформованим світоглядом, поглядами, переконаннями, уявою, мисленням, справжнім творцем навчально-виховного процесу, здатним розкрити свій духовний, індивідуально-неповторний творчий потенціал, реалізувати його у різних видах художньо-творчої діяльності, спрямувати цю діяльність на духовний розвиток особистості учня.

Таке широке розуміння музичної творчості містить у собі всю ємність і багатовекторність конкретно-специфічних виявів творчості у видах музичнопедагогічної діяльності майбутнього фахівця. 3 цієї позиції творчо-виконавська діяльність $є$ основою реалізації творчого потенціалу, самовираження, самоактуалізації і самореалізації особистості майбутнього вчителя у різних їі формах і видах. Акцентуючи увагу на розвитку творчої особистості в процесі активного оволодіння нею різноманітними видами творчої діяльності, педагогимузиканти вказують на значущість пї зворотного зв’язку й впливу на особистісний розвиток, зокрема, розвиток творчої індивідуальності (Г. Падалка, О. Отич), найповнішого розкриття творчих здібностей особистості (О. Ростовський), вияву власного художньо-педагогічного стилю і гуманістичного почерку (В. Орлов), емоційної обдарованості і самовираження (О. Олексюк, О. Рудницька), унікальності, самобутності, індивідуальної неповторності.

Творчість за законами краси, ядро якої становить мистецтво, є універсальною формою художньої діяльності. Творча діяльність - це діяльність майбутнього вчителя музичного мистецтва в їі особистісній, педагогічній i загальнолюдській значущості, передбачає інтеграцію естетикомистецтвознавчих, загальнохудожніх, фахових, педагогічних знань, їх застосування і реалізацію у практичній діяльності. 
У процесі творчо-виконавської діяльності реалізується особистісна креативність студента, яка, з одного боку, як суб’єктивна детермінанта творчості є iї мотиваційною основою, а 3 другого, як об’єктивна детермінанта творчості, розвивається й формується відповідно до особливостей та умов здійснення цієї діяльності, поступово досягаючи власної духовної вершини майбутнім учителем музичного мистецтва. Тому важливо знайти способи розкриття творчого потенціалу майбутнього вчителя, «розбудити» потребу i знайти способи реалізації цієї потреби у самовираженні. Здійснити це цілком можливо на основі пошуку музично-творчих рішень і їх матеріалізації у «композиторстві» як ключовому виді діяльності у творчій самореалізації і самовираженні. Така спрямованість на композиторсько-виконавську діяльність змінює позицію майбутнього вчителя не тільки як виконавця (інструменталіста, вокаліста, диригента), а й посилює його роль як учителя-композитора, вчителя-творця, розвиває потенційно-творче мислення, сприяє його прагненню до самовдосконалення, розвитку професійних якостей, бажанню виконати й оприлюднити власні твори.

У сфері музичного мистецтва творчість - це органічне начало, основа всіх інтонаційних практик, які охоплює система художньої діяльності. Основою цієї системи є тріада - композитор-виконавець-слухач, музична діяльність яких розрізняється за змістом, матеріалом і формою творчості, є конкретним способом вираження творчої дії, спрямованої на створення музичного твору, його виконання і сприйняття.

Музичний твір, який можна порівняти із живим організмом, - від його народження (задум та художня ідея композитора) до самостійного об'єктивного існування (інтерпретація, осмислення, критичне судження, оцінка), є цілісною інформаційною системою.

Основне завдання автора - залучити суб'єкта сприйняття у процес співтворчості. Через спів-творчість як певний спосіб діалогового спілкування здійснюється діалогічність свідомостей, розуміння іншого як самого себе, переживання «духу» музичного твору. У такій творчій діяльності, зазначають 
науковці, яскраво виявляється креативна активність людини, що має культурогенний характер. Так, у просторі художньої культури функціонують смисли, ейдоси (В. Бичков, О. Лосєв), які вступають у глибинний зв'язок із внутрішнім світом людини, актуалізуючи й стимулюючи іï духовно-творчий потенціал. Така принципова незавершеність художнього твору, його семантична відкритість передбачає спів-творчість з автором, характеризується граничною відкритістю до індивідуальних інтерпретацій. Поліваріантність творчих тлумачень та індивідуальних реакцій в процесі сприйняття-пізнання художнього образу уможливлюють визначення смислової конкретизації твору суб’єктом сприйняття як співтворчість. Такої ж думки дотримуються педагоги-музиканти (I. Кевішас, О. Олексюк, Г. Падалка, О. Ростовський, О. Рудницька та ін.), які зазначають, що суб’єкт художньо-діалогової взаємодії, використовуючи власний індивідуально-інтелектуальний, індивідуально-емоційний досвід художнього сприйняття, проникає в образний світ твору, осягає його світоглядний контекст, створюючи власну версію розуміння текстуального значення $[107$, с. 13, с. 16 , с. 18 , c. 19].

Здатність до співтворчості визначає рівень художнього пізнання i мислення і того, хто сприймає музичний твір, і виконавця-інтерпретатора. Як процес співтворчості аналізує виконавський процес С. Гуренко, стверджуючи, що цей процес є складною системою, містить художнє проектування результату виконавського мистецтва, процес формування виконавського задуму; реалізацію цього проекту як матеріального утворення [103]. Розкриваючи художній образ, виконавець привносить у художній образ свої переживання і співпереживання, видозмінюючи тим самим авторську інформацію, намагається її переосмислити, трансформує, бере участь у художній творчості, конкретизує, доповнює створені та втілені автором образи музичного твору, тобто є співтворцем. Як процес співтворчості, художню інтерпретацію визначають В. Асмус, Л. Виготський, Б. Мейлах, С. Раппопорт, П. Якобсон, Н. Яранцева та ін.

Отже, музичне виконавство як складний творчий процес не є первинною творчістю виконавця, а спів-творчістю, що не можна сказати про творчість 
автора (композитора), який, зазвичай, і є виконавцем-інтерпретатором власних творів. У цьому виявляється відмінна риса творчості і виконавства. А поєднує їх єдиний творчий процес, котрий містить елементи власне творчості і елементи виконавства: у процесі власного творення - композитор виконує, виконуючи, виконавець творить. У процесі творення творчість та виконання для автора єдині, нерозривні, взаємодоповнювальні й взаємозумовлені явища, - основою композиторської творчості завжди певною мірою $є$ виконавське начало, а основою виконавської творчості - композиторське начало.

Процес творчості («композиторства») і виконавства поєднує інтерпретація. У працях відомих філософів, психологів, музикознавців і педагогів, зазначається, що специфічною ознакою композиторської творчості і виконавства $\epsilon$ інтерпретація. Поняття «інтерпретація» як свого роду «супутник» або «тінь»супроводжує кожен феномен культури, будь-який мистецький твір. Мистецтво існує доти, поки існує його інтерпретація - виконавська, вербальна, тобто тлумачення словом і ділом. «Інтерпретація» (від лат. interpretatio посередництво - тлумачення, роз'яснення смислу) у мистецтві визначається як фундаментальна операція мислення, творче розкриття змісту художнього твору, що визначається ідейно-художнім задумом та індивідуальними особливостями артиста, співака, інструменталіста, диригента музичного твору у процесі його виконання.

Категорія інтерпретації посідає важливе місце в естетиці Р. Інгардена, Ф. Шлейєрмахера, В. Дільтея, М. Хайдеггера, Г. Гадамера, в естетичних концепціях яких ставиться питання про незавершеність художнього твору як особливої, унікальної якості мистецьких творів, що стимулюють творчу активність суб’єкта пізнання, оскільки в процесі художнього діалогу реципієнт доповнює образ власною уявою, фантазією. Питання інтерпретації як однієї з найактуальніших проблем музичної діяльності розглядаються у наукових працях Л. Бочкарьова, В. Блудової, Л. Гінзбург, Н. Горюхіної, А. Готсдинера, В. Григорьєва, Е. Громова, Є. Гуренко, А. Зися, М. Кагана, Г. Когана, 
Н. Корихалової, О. Костюка, К. Мартінсена, Л. Мазеля, В. Медушевського, Б. Мейлаха, Є. Назайкінського та ін.

Художня інтерпретація як трактування музичного твору в процесі його виконання $\epsilon$ результатом складних процесів, які являють собою систему взаємодіючих елементів із специфічними функціями, властивостями, структурою та змістом. Вона є активним творчим процесом, в якому воля композитора має стати волею інтерпретатора (С. Фейнберг), повноцінним самостійним видом художньої творчості (Л. Мазель), як діалектична єдність об'єктивізм і суб'єктивізм водночас - продуктом та функцією виконавця (Н. Корихалова); складним творчим процесом, що передбачає задум, творення художнього образу, проникнення в його інтонаційний зміст, розуміння i розкриття семантичного значення (Є. Гуренко); переведення семантичної конкретизації в художнє узагальнення, оформлення драматургічного задуму (В. Блудова); як суспільно-значущою цінністю (М. Каган), що розкриває соціальну реальність через світосприйняття композитора у процесі надання адекватної форми, змісту і значення відповідно до уявлень і художніх фантазій автора, розуміння художньо-образної сфери музичного твору.

Теоретичні концепції щодо структуризації, внутрішніх механізмів і змісту процесу художньої інтерпретації розробляються й досліджуються в наукових працях Л. Виготського, С. Рубінштейна, Б. Теплова, С. Фейнберга та ін. Вони містять визначення художньої інтерпретації як активного творчого процесу, художнього трактування музичного твору; як кінцевого результату виконавської діяльності, індивідуального художньо-образного відтворення й ставлення до музичного твору; як особливої духовно-практичної діяльності, у складній інтегративній структурі якої діалектично взаємодіють інтелектуальні та емоційні реакції, співпереживання, ідентифікація й співтворчість.

Представники сучасної теорії художньої інтерпретації розкривають питання впливу художньої форми та образного змісту на виконавця, значення дії та впливу засобів художньої виразності та їхніх специфічних особливостей на емоційно-почуттєву сферу інтерпретатора, здатність впливати на суб'єкта 
сприйняття і відтворювати складні процеси людської психіки. Важливими $є$ висновки науковців про те, що особистість майбутнього вчителя музичного мистецтва розвивається, формується і реалізується в художній інтерпретації і через художню інтерпретацію.

Отже, музичне виконавство $\epsilon$, безперечно, творчим процесом, a «творчість» передбачає створення нової продукції і не існує без виконавства. Але в контексті нашого дослідження поняття «творчо-виконавська підготовка майбутнього вчителя музичного мистецтва» набуває значущості та інноваційності, оскільки грунтується не тільки на здатності творчо сприймати, виконувати та інтерпретувати музичні твори (інструментальні, вокальні, хорові), самовиражатися у виконавській діяльності, а й передбачає здатність майбутніх учителів до самотворчості, бути водночас автором і виконавцем власного твору. Тому у творчо-виконавській діяльності особливого значення набувають такі види творчості, як композиція та імпровізація, що мають велике значенні для розвитку всього комплексу музичних здібностей, музично-образного мислення, зростання ефективності процесу засвоєння знань, формування умінь і навичок, необхідних i музиканту-фахівцю, i вчителю музичного мистецтва у їx професійній діяльності. Отже, у структурі творчо-виконавської діяльності виокремлюємо композиторсько-виконавську діяльність. Оптимальна цінність цієї діяльності досягається у тому разі, коли композитор і виконавець «зливаються» воєдино, тобто композитор є водночас інтерпретатором своєї музики. Він виконує дуже відповідальну роль в комунікативному процесі композитор - виконавець - слухач (аудиторія). Зазначимо, що ця схема-тріада фіксує остаточний результат диференціації видів музичної творчості, що склався у європейській культурі Нового часу й свідчить про структуру художньотворчого спілкування.

Варіантом «композиторства» є мистецтво імпровізації, яка в епоху бароко і класицизму, спираючись на традиції ренесансного мистецтва, була хранителем пам'яті про одвічну цілісність творчості як феномена, про первісний синкретичний характер творчого процесу, в якому імпровізатор - це творець 
музики і виконавець в одній особі, а створення музики та їі звукова реалізація становлять нероздільну єдність.

Навчання імпровізації $є$ фактором розвитку спеціальних здібностей, (слухових уявлень, почуття ладу і ритму), особистісних якостей (креативності, емоційної чуттєвості), здатності переживати «форму як процес» (Б. Асаф’єв), творчо «мислити звуками», «реалізувати в діяльності специфічну музично-мовну здатність» (М. Арановський). Крім цього, імпровізація допомагає глибше зрозуміти закономірності гармонічної мови, усвідомити художньо-виражальну та формотвірну роль гармонії у комплексі 3 іншими засобами музичної виразності в художньо-цілісній побудові. Основними показниками сформованості вмінь імпровізаційної художньої техніки як варіативного потенціалу композиторсько-виконавської діяльності студентів $є$ : високорозвинена інтонаційно-слухова підготовка, усвідомлення музичних уявлень; розвиненість мелодичного та гармонічного слуху, музичного мислення, почуття форми, стилю і жанру; розвиненість художньо-стильового і художньослухового досвіду, володіння інтонаційними, метро-ритмічними, фактурними, структурними стереотипами музики різних стилів і жанрів; розвиненість музично-виконавської техніки, володіння навичками творчо-виконавської інтерпретації; розвиненість умінь миттєвого перетворення музичних образів на внутрішні слухові уявлення та їх реалізація у звучанні на інструменті або голосом; здатність перетворювати наявні у пам’яті музичні образи, створювати на цій основі нові, власні. Володіння імпровізаційною технікою, як варіативним потенціалом композиторської творчості, передбачає й, водночас, впливає на розвиток музичного слуху, асоціативно-образного мислення, сприяє удосконаленню виконавської техніки (вокальної, інструментальної), здатності миттєвого перетворення музичних образів на внутрішні слухові уявлення та їх реалізацію у звучанні голосом або на інструменті; формує почуття форми, художнього стилю і жанру; здатність розуміти закономірності музичної мови, усвідомлювати виражальну та формоутвірну функцію засобів музичної виразності (гармонії, мелодії, метро-ритму та ін.), метро-ритмічні, інтонаційно- 
фактурні, структурні стереотипи музичних творів різних стилів; здатність перетворювати наявні у пам’яті музичні образи та здатність створювати на цій основі нові, «вплітати» до індивідуального досвіду та аксіологічної сфери студента нові смисли, стимулювати творчу самоактуалізацію, виникнення потреби у творчому самовираженні, збагаченні творчо-виконавського досвіду, розкріпаченні й розкритті власних творчих можливостей.

Основи композиторської та імпровізаційної техніки закладаються у всіх фахових дисциплінах, розвиваються і формуються у процесі цілеспрямованої навчально-творчої діяльності у їі специфічних формах (композиція, імпровізація, творче музикування). Особливістю цих креативних якостей $\epsilon$ те, що вони $\epsilon$ точкою перетину різних видів художнього мислення, зокрема, історикостильового, інтонаційного, інтерпретаційного, наближають навчання до художньої практики. Широкі можливості у цьому плані надають музичнотеоретичні дисципліни, зокрема «Історія музичного мистецтва», «Теорія музики та сольфеджіо», «Гармонія», «Аналіз музичних творів», «Поліфонія», «Акомпанемент та імпровізація», «Основи музичної композиції», «Основи композиторської майстерності» за умов тісного зв’язку з предметами музичновиконавського і практично-методичного циклів. Тісний зв'язок між творенням і виконанням музики, композитором i виконавцем, функції яких часто поєднувались (композиторська діяльність виконавця і виконавська діяльність композитора) зумовлюються самою художньою практикою, системою виховання i навчання музиканта, нерозривним зв'язком композиторського i виконавського таланту.

Шлях до «композиторства» пролягає у тріаді взаємодійних i взаємозумовлених понять «сприйняття-виконання-творення» у їх логічній послідовності, що передбачає наявність складних взаємозв’язків, які грунтуються на художній інтерпретації, здатності творчо осмислювати зміст художніх творів.

Розкриваючи педагогічний аспект «композиторства», акцентуємо увагу на відмінності підготовки композитора на композиторських відділеннях 
консерваторій (музичних академій), які готують професійних композиторів і формування особистості композитора-виконавця на музичних відділеннях мистецьких і музично-педагогічних факультетів, підготовка якого здійснюється у тісному зв'язку індивідуально-особистісного, творчо-виконавського й педагогічного напрямів й спрямовується на музичне виховання підростаючого покоління, що у результаті дає змогу схарактеризувати майбутнього вчителя музичного мистецтва як цілісну особистість, самостійну, ініціативну, мобільну, винахідливу, креативну, компетентну, здатну до адекватної інтерпретації музичних творів, власного творення у різних жанрах, стилях і формах; (пісні для дітей, окремі музичні твори, музично-театральні вистави, мюзикли, творчі проекти, видовищні заходи), котрий володіє методикою навчання, залучає й навчає власного творення студентів інших курсів та інших мистецьких спеціальностей (майбутні учителі хореографічного та образотворчого мистецтва), встановлює творчий діалог з аудиторією, виявляє відповідальність та ініціативу у творчо-виконавській діяльності в інших навчальних закладах, застосовує i винаходить власну методику творчо-виконавської діяльності, спонукає до творчості своїх вихованців. Тому мета «композиторства» як інтегративної дефініції має полягати не тільки у навчанні студентів створювати власні твори у рамках певної дисципліни, а у спрямуванні цієї діяльності на майбутню професію - вчитель музичного мистецтва, а також на можливість саморозвитку, самовираження і самореалізації майбутнього фахівця в інших сферах соціально-культурного середовища (гімназії, коледжі, музичні школи, дитячі юнацькі центри, школи мистецтв, театр, філармонія та ін.).

Композиторсько-виконавська діяльність як процес духовно-практичного втілення художньої ідеї у чуттєво сприймані художні образи , своєю кінцевою метою і результатом передбачає досягнення максимальної відповідності між творчим задумом композитора та його адекватним утіленням у своєрідній образній мові музичного мистецтва. Цей процес об’єктивації художніх образів у засобах музичної виразності, відповідній формі, стилі, образі, змісті, що склалися 
в уяві автора, набуває життєвої повноти, внутрішньої потреби і необхідності художньо висловитися і втілитись у творі як цілісна художня ідея.

Складний процес композиторсько-виконавської діяльності має об’єктивний і суб’ єктивний аспекти. Автор розкриває проблеми навколишнього життя, відтворює складні процеси людської психіки, відображує реальне життя у формах самого життя й виражає власні почуття і прагнення. У такому творчому процесі реалізується внутрішній ресурс, відбувається народження унікального неповторного художнього образу.

Композиторсько-виконавський процес $\epsilon$ складним i відповідальним. Автор, використовуючи єдину об'єктивну основу - навколишній світ, життя в усій його складності та багатогранності, пізнаючи об’єктивну реальність, не обмежений у пошуках життєвого матеріалу, вільний у доборі тем майбутнього твору, індивідуально планує процес творення, добирає такий тематичний матеріал, що найбільш розкриває його внутрішній світ і світоглядну позицію.

Об’єктивний фактор - це прагнення об’єктивації духу в матерії формування, причому воно набуває характеру мети; суб'єктивний - це здатність суб’єкта (автора) заглиблюватися у сутність явищ та формувати образи їх життєвості як ідеальну реальність у у засобах художньої виразності, вміння у художньо-творчому процесі досягати адекватності втілення художніх образів, що живуть у свідомості митця, у матеріалі мистецтва.

Важливою закономірністю творчого процесу $є$ акцент на самоцінності потреби об’ єктивації духовного досвіду у власній творчості. Жодні інші мотиви, на думку психологів, не можуть виконувати конструктивну роль у процесі творчості. Це якісно відрізняє практичне і духовне формування. У діяльності практичного формування метою зусиль суб'єкта постає задоволення певних життєвих потреб, тоді як метою практичного формування постає творення як «свободи від...», тобто звільнення від життєвих потреб способом їх задоволення. Простір свободи створюється саме завдяки можливості задовольнити життєві потреби. У процесі художнього творення має місце інша закономірність: митцем рухає потреба входження у простір «свободи для...», i для розгортання 
життєвості духу в матерії художнього формування. Процес художнього творення вимагає, щоб автор жив власним твором, надихався і проникався в задум, утримував його образи та окремі деталі до завершального етапу художньоінтерпретаційного процесу, в якому «дух животворить» (Г. Сковорода) i «здобуває реальне життя», втілюючись у своєрідні художні образи. Композиторсько-виконавська діяльність як процес розгортається у формах внутрішньої потреби, котра набуває характеру необхідності та реалізує себе в музичній формі і змісті, досконалих художніх образах як вільна внутрішня життєвість духу. Художньо-формувальні вміння як суб’єктивна здатність - це, 3 одного боку, розвиток та концентрація у суб'єкті родових духовних якостей: багатої уяви, фантазії, пам’яті, творчого мислення, що дають змогу свідомості формувати цілісні образи, рознюансовуючи багатство їх життєвості. 3 іншого боку, - це уміння досконало, майстерно, життєво втілювати образи свідомості у матеріалі конкретного виду мистецтва. Оскільки суб’єктом рухає потреба об’єктивувати творчий дух в художніх образах, вона (потреба) є активною силою, що спонукає вміння та здібності на формування і втілення художнього образу у відповідній формі. Тому, саме творчий дух є тією силою, що стійко утримує потребу формування, визначає змістовність процесу та спонукає волю на втілення художнього задуму в матеріалі мистецтва, тобто організує здатність суб’єкта до художнього творення.

Духовна потреба суб’ єкта - надати чуттєво сприйманого втілення образам, що склалися в уяві, набули виразних форм і внутрішніх зв’язків і постають у пам’яті сповненими життєвої повноти та переконливості. Митець (композитор, художник, поет) бачить їх у найменших деталях. Думки, почуття, уява, пам’ять стійко утримують образи, що заволоділи свідомістю і «вимагають» втілення $\mathrm{i}$ відображення себе специфічною мовою твору, надихають на художнє формування, коригують початком творчого формування, «підказують» способи, внутрішню спрямованість свого ідеального життя в музичній формі, зумовлюють необхідність постійно уточнювати попередній задум згідно 3 об’ єктивною логікою його розвитку і формування як художнього цілого. Автор 
реалізує свій задум у діалектичному зв'язку з ідеєю та ії втіленням в художньообразній мові твору, використовуючи комплекс художньо-формувальних умінь.

Схильність до мотивованої композиторсько-виконавської діяльності зумовлена наявністю індивідуальних здібностей, здатностей і властивостей особистості, котрі розкривають специфіку і зміст цієї діяльності більш повно і глибше, а отже, й особистість автора. Інтерес, захоплення і схильність, що виникли, є потребою самовираження особистості у цій діяльності. Отже, основною спонукою до творчості є внутрішня потреба автора (композитора) надати реального життя художнім образам, що живуть в уяві та утримуються пам'яттю. Потреба зосереджує на собі, породжує велику творчу наснагу. Тому метою формувального процесу в композиторсько-виконавській діяльності $\epsilon$ закріплення цієї потреби, ставлення у його найбільш повному, цілісному, художньо-переконливому виявленні. Внутрішня правда художніх образів, що живуть у свідомості автора, дає можливість поглиблювати, вдосконалювати, наповнювати їх новими рисами життєвості, внутрішньої досконалості і завершеності, є джерелом творчої наснаги, спонукає на подальшу творчовиконавську діяльність.

Композиторсько-виконавська діяльність, що грунтується на сприйняттіінтерпретації, пов'язана передусім з «афективними» процесами (емоції, почуття, бажання), що становлять основу спонукальної регуляції як вираження активного ставлення, викликаного зіткненням наявного 3 належним, прагнень i можливостей їх реалізації, ідеалів і дійсності. Емоції як «енергетичне пальне» аферентного синтезу всіх наявних подразників у поєднанні з минулим досвідом, сигналізують про значущість відображуваного, дають установку до сприйняття i дії, активізують організм, об’єднують усі компоненти психіки, сприяють формуванню як ідеальних моделей реальних процесів і явищ, так і тих, що передбачається створити і відобразити. Художня емоція набуває особливого значення у формуванні творчого потенціалу особистості. Ї̈ї відносять до «стенічних» емоцій, що стимулюють життєдіяльність людини, активізують, мобілізують і актуалізують творчі сили особистості. 
Повноцінне творення відбувається тоді, коли композитор-виконавець розкриває не тільки загальні риси образного змісту і форми, а й своєрідне, неповторно індивідуальне авторське втілення, вступає у діалог із самим собою. Такий складний процес творення й осягнення змістової форми передбачає мобілізацію різноманітних знань (загальнохудожніх, музично-теоретичних, музично-історичних тощо) i вмінь (художньо-інтерпретаційних), які уможливлюють вияви власних почуттів і переживань, що є «надпредметним» результатом композиторсько-виконавської діяльності. Цей процес передбачає оригінальні вияви особистісних художніх вражень, емоційне забарвлення, індивідуально-неповторні, суб’єктивно-асоціативні уявлення.

Провідними компонентами композиторсько-виконавської діяльності $є$ логічне мислення, пізнання, переживання, інтуїтивне осягнення змісту художніх образів, уява, душевно-емоційна і практично-діяльнісна сфери особистості. Художнє пізнання - це розуміння смисло-образів, які підносяться і над звичайними образами, і над поняттями в осягненні різних аспектів буття і співбуття з іншими, це шлях до духовних вимірів у злагоді розуму, волі і почуттів.

У сфері мистецької освіти «пізнання» інтерпретується як узагальнення, як процес і результат усвідомлення тих значень, які притаманні мистецтву, як феномен образного відображення дійсності, взаємодія суб'єкта (учня) і об'єкта (художнього твору), спрямована на усвідомлення змісту і форм художніх образів, на досягнення нового знання щодо мистецтва [115, с. 88].

Мислення у мистецтві набуває в художньо-образних формах особистісного сенсу, оскільки воно завжди емоційно забарвлене. Мислення $\epsilon$ основою композиторсько-виконавського процесу і спирається на пізнання i розуміння «інтонаційного словника» епохи, ii художньо-стильових особливостей, що не може відбуватися без пізнання і розуміння навколишньої дійсності. Логічне мислення передбачає пошук оптимальних способів вираження власного художнього задуму, його втілення в художню форму. Раціональноінтелектуальні способи пізнання, логічно-оперативні дії автора, аналіз, синтез, узагальнення, систематизація спонукають до пошуку нестандартних рішень, 
створення нового, раніше небувалого, внаслідок чого відбувається активізація мисленнєвих процесів.

Процес композиторсько-виконавської діяльності передбачає інтуїтивнологічне оперування образами-симолами, вимагає від інтерпретатора суттєвого переосмислення, подолання педагогічного стереотипу щодо інформативнопізнавальної домінанти, виявлення й увиразнення специфіки музичної семантики, що передбачає участь таких когнітивно-почуттєвих механізмів як індивідуальне «вчуття», внутрішне «вживання» в художній образ, асоціативність, емоційно-естетичний резонанс.

Аналітико-синтетична діяльність свідомості автора зумовлює виникнення емоцій, що завжди супроводжують творчу дію, впливають i стимулюють продуктивність когнітивно-розумового процесу, поступово набувають осмисленості й концентрованості, містять значні інтелектуальні потенції й виконують пізнавальні функції, є «глибокодумними» (Б. Теплов) і «розумними» (Л. Виготський). Саме емоції істотно доповнюють інтелект людини при творчому розв’ язанні проблеми. Вказуючи значення емоцій і почуттів у процесі художньої творчості, Л. Виготський у відомій науковій праці «Психологія мистецтва», зазначає, що «всіляке почуття, всіляка емоція прагне втілитись у певні образи, що відповідають цьому почуттю» [101].

Раціонально-інтелектуальні й емоційно-мисленнєві процеси передбачають проектувальні підходи, постановку мети, iї інтелектуальне обгрунтування, осмислення творчого завдання й активізують процес творчості. Внаслідок такої складної творчої взаємодії емоційно-інтелектуальних процесів, асоціативнообразного мислення, вмінь знаходити різні зв’язки в цілісному художньому об'єкті стає можливим процес співпереживання, проникнення, інтеріоризація художнього змісту, повноцінне художньо-діалогового спілкування, як у процесі безпосередньої художньої комунікації, так і на посткомунікативному етапі, що передбачає внутрішній діалог автора зі своїм внутрішнім «Я» (М. Бахтін, М. Каган). 
У композиторсько-виконавській діяльності значну роль відіграє натхнення як особливий стан людської психіки, що передбачає підвищену творчу активність індивіда, високу інтенсивність процесу мислення. Але при всій мимовільності, як це вважається, натхнення визначене. Умовою натхнення є усвідомлення суспільної значимості художнього завдання, захоплення художньою ідеєю, що має втілитися в художньо-образний зміст музичного твору. Передумовою натхнення є минулий досвід, праця, роздуми, міркування. Результатом натхнення є виникнення і реалізація художнього задуму та ідеї.

Процес власного творення, сприймання і розуміння художніх творів учені тлумачать як «діалог», адже автор, як взаємодійна сторона художнього діалогу, постає у свідомості інтерпретатора зі своєю художньо-смисловою позицією, що спричиняє внутрішній діалог інтерпретатора (діалог між внутрішнім світом особистості й духовним «Я» музичного твору, образно-художньою моделлю). У працях «Світ спілкування», «Мистецтво і спілкування» М. Каган виокремлює таку форму художнього діалогу у процесі спілкування з музичними творами, як творча імпровізація (автор та співавтор-інтерпретатор), діалог яких спричиняється програмою музичного твору, «спільною темою», взаємодія окремих партій в ансамблі, діалог виконавця і слухача).

Процес композиторсько-виконавської діяльності як творчий процес передбачає вияв індивідуального стилю автора (композитора) як у процесі творення, так і у процесі художнього виконання (інтерпретації), що, зазвичай, сприяє формуванню активного творчого ставлення особистості до навколишньої дійсності й до самого себе. Створюючи свої творіння, композитор «мислить своїм слухачем», котрий присутній в авторському творчому процесі як мета, для якої створюються твори. Здійснення такої духовної «взаємності», взаємопрагнень до художнього спілкування - це стиль, у якому здійснюється художня комунікація (реальність - творець - твір - виконавець - реціпієнт дійсність), засвідчується особистість автора, що закладена в ритмі, інтонації, гармонії, засобах виразності. 
У інтегративній духовно-практичній діяльності автора-інтерпретатора діалектично взаємодіють інтелектуальні та емоційні реакції, співпереживання, ідентифікація і співтворчість, що відзеркалюють динаміку емоційних реакцій від безпосередньо-чуттєвих виявів до вищих емоцій художньої насолоди. Саме в такому творчому процесі здійснюється художньо-образне трактування й ставлення до музичного твору, стає можливим процес співпереживання, проникнення і «вживання» в художній образ, інтеріоризація художнього змісту, повноцінного діалогового спілкування.

У процесі власного творення розвивається творче, художнє мислення, оскільки це перш за все створення нової реальності, адже художній твір народжується в уяві митця (композитора, художника, архітектора, драматурга, хореографа, режисера тощо) й, водночас, спрямовується до художньо-творчих обдаровань особистості, без яких неможливий процес композиторськовиконавської творчості

Провідну роль у процесі композиторсько-виконавської діяльності відіграє розвинута уява та фантазія автора, що грунтуються на емоційно-почуттєвих процесах. Досліджуючи проблеми сутності уяви, психологи одним із механізмів iï виникнення називають емпатію як своєрідний різновид уяви, оскільки в процесі емпатійного сприймання людина «переносить» себе до думок, почуттів i дій іншого та структурує власне сприймання за цим зразком. «Я» нібито поділяється на реальне «Я» і уявне «Я». Це уявне «Я» і $є$ творчим компонентом. Емпатія, як у процесі слухацького сприймання, так і в процесі власного творення передбачає тісну взаємодію когнітивно-розумових, емоційно-почуттєвих і художньо-творчих актів, характеризується багатством асоціативно-образних уявлень, вміннями суб'єкта художнього творення-інтерпретації осмислювати організацію художнього матеріалу, розуміти виразний сенс художньої інтонації і є генералізованою професійно значущою особистісною якістю майбутнього вчителя музичного мистецтва.

У процесі власного творення активно діють механізми синтонії та ідентифікації, тобто перенесення життєвих станів інших людей на себе, свою 
долю, співчуттєве ставлення до сприйнятого, що містять елементи взаєморозуміння, безкорисливої допомоги. і посідає центральне місце в процесі формування здатності суб’єкта до самопізнання та саморозвитку (А. Фройд, Д. Рапопорт). Зумовлюючи виникнення ефекту емоційної ідентифікації (Г. Андреєва, Т. Шибутані), глибокого співпереживання й співчуття, здатність до емпатії позитивно позначається на духовному міжособистісному спілкуванні, гуманізує систему педагогічних дій i впливів, сприяє встановленню повноцінного діалогу в процесі художньо-педагогічної взаємодії викладача i студента, набуває педагогічного сенсу. Саме через нього (співпереживання) відбувається збагачення внутрішнього світу особистості досвідом почуттів інших людей. Через пристосування до емоцій інших студенти можуть відчувати соціальні, моральні, естетичні почуття, яких у їхньому практичному досвіді ще не було. Особливо важливо зауважити гуманістичну спрямованість співпереживання, у процесі якого формується ставлення до людини.

Одним із положень психології мистецтва $є$ теза про те, що в процесі художнього сприйняття-інтерпретації здійснюються психологічні перетворення, аналогічні авторським, що їх він переживає у процесі створення твору; душа виконавця і того, хто сприймає, «зливається» 3 душею автора, і що саме у цьому поєднанні і є головна приваблювальна сила та властивість мистецтва. Тож стає зрозумілою значущість композиторсько-виконавської творчості майбутніх учителів музичного мистецтва, в процесі якої відбувається особлива активізація свідомості через власне відтворення цінності буття засобами специфічної мови музичного мистецтва. Процес власного творення не тільки збагачує майбутніх фахівців життєвим і художнім досвідом, a й спонукає їх до ціннісного переживання, що становить важливий компонент їхньої світоглядної i гуманістичної позиції.

Художня насолода, що охоплює автора-виконавця і слухача в момент оприлюднення твору і є оцінкою здатності автора створювати твір як художнє ціле, є реакцією на його творіння як на високу соціальну цінність. 
Здатність насолоджуватися мистецтвом характеризує високий рівень емпатійного проникнення в його образний зміст $\mathrm{i}$ водночас багатство внутрішнього світу суб'єкта художньої взаємодії. Катарсис, як форма вияву почуттів, у процесі художнього спілкування виникає завдяки здатності суб'єкта ототожнювати, ідентифікувати, емоційно переживати, перевтілюватись у художні образи, проникати в їхній внутрішній світ, «пропускати через себе». Отже, емоційно-емпатійне співпереживання автора-виконавця $є$ показником володіння ним почуттєвою проникливістю, багатством асоціативно-образних уявлень, вміннями художньо мислити, розуміти організацію музичного матеріалу, виразний сенс інтонації.

Психолого-педагогічний аналіз процесу художньої творчості, внутрішніх механізмів сприйняття-інтерпретації, творення дає змогу констатувати, що у процесі композиторсько-виконавській діяльності формуються універсальні особистісні професійно значущі якості (логічне мислення, творча уява, асоціативність, креативність, здатність до емпатії і рефлексії, ціннісні орієнтації) і таким чином, набуває потужності духовно-творчий потенціал особистості.

У процесі композиторсько-виконавської творчості передбачається «вивести» студента на такий рівень самосвідомості, де творче самовдосконалення у різних видах «композиторства» i творчо-виконавській діяльності стане природним станом майбутнього фахівця. Це, в свою чергу, стимулює творчу активність, опосередковує формування внутрішніх мотивів $\mathrm{i}$ цінностей щодо своєї професії, творчості і значущості самого себе у цій діяльності, формує якісно нову професійно вагому якість майбутнього вчителя музичного мистецтва - авторську спроможність.

У формуванні авторської спроможності майбутніх фахівців особливої значущості набуває метод проектів. Творчий проект «Я - композитор» визначається своєю динамічністю, оскільки забезпечує зміну форм надання $\mathrm{i}$ одержання знань - від формування художнього сприйняття - до активної участі у різних видах творчо-виконавської діяльності і самовираження у власній творчості, від індивідуальної до групової і колективної співтворчості. Вимогами 
проектної технології є: усвідомлення теоретичної, пізнавальної і практичної значущості передбачуваних результатів; спрямованість на розвиток пізнавальних умінь та навичок, здійснення самостійної пізнавальної діяльності студентів; здатність до самостійної пошукової діяльності, структурування змістовної складової творчого проекту з поетапним узагальненням результатів; оприлюднення і впровадження отриманих результатів творчого застосування набутих знань, узагальнення та інтеграція музично-теоретичних, музичновиконавських, практично-методичних, науково-дослідних знань і вмінь, набутих у процесі теоретичного, практичного навчання та самостійної роботи, здатність орієнтуватися в інформаційному просторі та добирати необхідні знання, узагальнювати та інтегрувати набутий досвід, використовувати його у нових умовах і власній продукції. Окрім того, залучення майбутніх фахівців до проектної діяльності сприяє розвитку ініціативи, комунікативності, організаторських та творчих здібностей. Участь у творчо-проектувальній діяльності надає можливість майбутньому вчителю (викладачеві, вихователю) самовдосконалюватися, відкриває можливості для вибору своєї ролі у творчому проекті: автор художньої ідеї, композитор, виконавець, артист, організатор або студент, який виконує власний твір, виступає в одній особі в усіх ролях (монопроект), самостійно його проектує i моделює, інтерпретує, доповнює презентацією (мультипроект).

Ефективність проекту «Я - композитор» зумовлюється основними його характеристиками: орієнтованість на самостійну діяльність; можливість використання різноманітних методів, засобів, що грунтуються на інтеграції набутих поліхудожніх, музично-теоретичних знань, художньо-інтерпретаційних умінь 3 різних дисциплін, галузей мистецтва і педагогічної науки. Названі характеристики відображають провідні закономірності музично-педагогічної освіти: самостійність у прийнятті рішень; здатність до творчості, усвідомлення внутрішніх спонук, мотивів, потреби, інтересів, які виступають регуляторами поведінки; міждисциплінарність, інтеграційність, здатність до самовираження і самореалізації, оцінки і самооцінки. 
Авторська спроможність набуває інтегративного характеру, містить внутрішні індивідуально-особистісні характеристики, здатності, якості і властивості, що виявляються у композиторсько-виконавській діяльності майбутнього вчителя музичного мистецтва. Надаючи «життя» своїм індивідуальним цінностям, досягаючи свідомої мети, реалізуючи її у діяльності, майбутній фахівець утверджує себе як неповторну особистість, спроможну досягнути широких творчих узагальнень, демонструвати високий рівень культури, грамотність, глибоку ерудованість й інтелектуальність, гармонію і красу внутрішнього світу, небайдужість до навколишнього середовища, усвідомлення його цінностей і свою причетність до створення цих цінностей. 